\title{
Determinanty oddalování početí dítěte
}

\section{Determinants of Childbirth Postponement}

\author{
Zdeňka Lechnerová
}

\begin{abstract}
This article focuses on the current demographic process that is discussed in the public and academic spheres. The aim of the paper is to describe and analyse reproductive strategies of young people aged 27 to 29 living in the Czech Republic. With the help of quantitative data analysis we examine the determinants of the postponement of parenthood and expectations associated with the parenting role. The main questions that are answered are: What are the factors affecting postponement of parenthood? Are there any differences in the reproductive strategies within this selected age group according to sociodemographic characteristics? What are the reasons why young people aged 27 to 29 years remain childless? What are the expectations of these young people associated with childbirth? The analysis reveals that young people are postponing parenthood because of their economic and housing situations. Other significant reasons include insufficient psychological preparation for the role of being a parent and the lack of a stable partnership suitable for parenthood. Young people expect there will be financial costs from having a child directly after birth. They also consider the limitations on their personal freedom and free time caused by childrearing, and they expect increased physical and psychological difficulty to be caused by child care.
\end{abstract}

KEYWORDS Barriers of parenthood, expectations, birth rate, postponing the childbirth, fertility.

\section{1. Úvod}

Mít rodinu a žít rodinným životem, jehož součástí jsou i děti, je jednou z priorit v životě většiny mužů a žen v české společnosti. Právě rodina a děti zastávají podle výsledků výzkumů provedených v uplynulých letech v České republice zcela zásadní roli v životě lidí a obojí se řadí na nejvyšší prř́čky hodnotového žebříčku (Kučera 2000b, Kuchařová 2003, Šamanová 2006, Št'astná 2007), přestože současné možnosti mladých lidí (vzdělávání, profesní kariéra, cestování a volnočasové aktivity) by mohly snadno rodičovství konkurovat.

Většina mladých Čechů a Češek chce mít děti (Kučera 2000a, Šalamounová, Šamanová 2004). Avšak před tím, než se rozhodnou mít dítě, přemýšlí nad svojí situací a svými možnostmi. Zvažují, zda jsou dostatečně ekonomicky připraveni, zda dosáhli požadovaného

Sociálni studia. Katedra sociologie FSS MU, 4/2011. S. 87-104. ISSN 1214-813X. 
vzdělání a zda si splnili své kariérní plány. Rozhodují se, zda chtějí omezit svůj volný čas a své aktivity péčí o své dítě.

V České republice klesá od osmdesátých let minulého století míra úhrnné plodnosti, vzrůstá podíl celoživotně bezdětných lidí (Rychtaříková 2003) a dochází ke zvyšování průměrného věku matek při narození prvního dítěte (Pohyb obyvatelstva, bez vročení). Mladí muži a ženy odkládají narození prvního dítěte do vyššího věku, čímž se zvyšuje pravděpodobnost početí menšího počtu dětí, než kolik by si ženy a muži přáli mít. Podíl celoživotně bezdětných lidí vzrůstá $\mathrm{v}$ důsledku dobrovolné nebo nedobrovolné bezdětnosti.

Cílem článku je představit reprodukční strategie lidí ve věku od 27 do 29 let žijících v České republice. Zaměřím se na analýzu determinantů odkládání početí (dalšího) dítěte do pozdějšího věku, s cílem odpovědět na následující otázky: Jaké faktory ovlivňují odkládání početí dítěte do vyššího věku? Liší se reprodukční strategie mezi vybranými skupinami mladých lidí podle jejich sociodemografických charakteristik? Z jakých důvodů jsou mladí lidé ve věku od 27 do 29 let doposud bezdětní? Jaká očekávání spojená s narozením dítěte mají?

Článek je rozdělen do tří kapitol. V první části se zaměřuje na vývoj plodnosti, její charakteristiky v současné české společnosti a na reprodukční strategie mladých lidí. Následuje analýza determinantů odkládání početí dítěte do pozdějšího věku. Poslední kapitola je zaměřena na očekávání, která s příchodem dítěte mladí lidé v této věkové skupině spojují.

\section{Data}

Pro účely analýzy budou použita data z panelového výzkumu Páry a rodiny probíhajícího již čtvrtým rokem na Fakultě sociálních studií v Brně. V tomto výzkumu jsou sledovány dvě věkové skupiny sestávající z lidí, kterým v roce 2008 bylo mezi 15-17 a 25-27 lety. V roce 2010 proběhla již třetí vlna sběru dat od respondentů participujících na výzkumu v letech minulých a současně byl uskutečněn dosběr u 1100 mladých mužů a žen již ve věku 17-19 a 27-29 let. Pro účely tohoto článku budu pracovat pouze s daty sesbíranými v roce 2010 od mladých mužů a žen ve věku od 27 do 29 let. Vzorek, se kterým budu pracovat, se skládá z 949 respondentů.

Záměrná práce pouze $\mathrm{s}$ touto věkovou skupinou spočívá $\mathrm{v}$ mém předpokladu, že mladí lidé v tomto věku přemýšlejí o svých reprodukčních záměrech a začínají tyto záměry realizovat. ${ }^{1}$ Dá se tedy očekávat, že jejich výpovědi na otázky týkající se tématu rodičovství již nebudou v takové míře hypotetické, jak by bylo možné očekávat u skupiny mužủ a žen ve věku od 17 do 19. Předpokládám, že tito lidé by měli mít představu o tom, zda chtějí mít dítě (děti), proč odkládají narození (dalšího) dítěte a jaká mají očekávání od jeho příchodu do jejich života.

Mladí lidé ve věku od 27 do 29 let zastoupeni ve vzorku jsou ve $26,3 \%$ př́ípadech rodiči, zatímco ve skupině 17 až 19 let je tomu tak u 6,6 \%. Vyšší zastoupení skupiny rodičů je zásadní pro analýzy prováděné dále $\mathrm{v}$ textu, jelikož budu porovnávat výsledky odpovědí za skupiny rodičů a bezdětných (a samozřejmě i jiných skupin mladých lidí podle sociodemografických charakteristik). 


\section{Plodnost a bezdětnost}

Míra úhrnné plodnosti a podíl bezdětných mužů a žen se $\mathrm{v}$ průběhu vývoje lidských dějin mění podle ekonomické, sociální a kulturní situace a hodnot, které muži a ženy ve společnosti uznávají a zastávají. Tyto změny vedly ke dvěma výrazným demografickým přechodům, $\mathrm{v}$ rámci kterých došlo ke snižování míry úhrnné plodnosti. Druhý demografický zvrat probíhal v západní Evropě od šedesátých let 20. století, ve kterých hodnoty míry úhrnné plodnosti poklesly až pod hranici hodnoty 2,1 . Tato hodnota je nezbytná pro zachování současné velikosti populace. $\mathrm{V}$ této době docházelo na území Evropy $\mathrm{k}$ zásadním změnám v sociálních systémech, prohlubovala se ekonomická nestabilita a krize, současně sílil vliv ženských hnutí, která odmítala propojení mezi ženstvím a mateřstvím, a byla vyvinuta účinná antikoncepce (Možný, Pakosta a Přidalová 2008). Právě využívání nové a efektivní formy antikoncepce (pilulek) mělo za následek eliminaci většiny neplánovaných početí a posunování početí prvního dítěte do pozdějšího věku (Lesthaeghe a Moors 2000: 123-124). Antikoncepce se tak stala nástrojem nových hodnot, které mohly ženy přijímat libovolně podle svého přesvědčení. Ženám bylo umožněno rozhodnout se, kdy chtějí přerušit profesní dráhu a mít dítě, nebo zda si zvolí život bez dětí.

Změny na makroúrovni probíhaly ruku $v$ ruce se změnami na mikroúrovni. Populace přijala $v 60$. letech minulého století změny hodnotového systému, které vyzdvihly individualistické hodnoty oproti altruistickým hodnotám (Rabušic 2001). Ty doposud přetrvávaly na hlavních príičkách hodnotového žebříčku. Hlavním mottem života jedince se mělo stát dosažení sebenaplnění a seberealizace. Založení rodiny přestalo být jedinou možností dosažení tohoto cíle. Tato změna hodnot hrála podle van de Kaa (1996) hlavní roli v druhém demografickém přechodu.

Změny na mikro- a makroúrovni zapř́íčnily pokles míry úhrnné plodnosti. Vývoj poklesu úhrnné plodnosti neprobíhal ve všech evropských zemích stejným způsobem a neměl stejnou intenzitu a směr (Lesthaeghe a Moors 2000). Výrazné rozdíly můžeme sledovat mezi západními zeměmi a státy na východě, které prošly socialistickým režimem. Trend snižování hodnoty úhrnné plodnosti se v zemích střední a východní Evropy projevil až zhruba o třicet let později než na západě. Změna instituce rodiny a proměna reprodukčních strategií mladých lidí měla podle Becka (2004) příčinu v přechodu socialistických zemí na tržní hospodářství, které nastavilo nový hodnotový systém. Hlavní hodnotou v životní dráze člověka byl ustanoven individualismus orientovaný na profesní kariéru, které se podřizují ostatní aspekty životní dráhy. Moderní, tržně ekonomická společnost umožňuje mužům a ženám volit si a takřka sestavovat si své životy podle svých přání. Mladí lidé mají tu možnost ${ }^{2}$ vybrat si mezi tím, zda chtějí studovat, cestovat, věnovat se kariéře či svým zálibám, nebo mít dítě.

Přestože se makroekonomické změny a změny $\mathrm{v}$ hodnotovém systému nově postaveném na tržně ekonomických hodnotách v postsocialistických zemích výrazně projevily až se třicetiletým zpožděním, dosahují míry úhrnné plodnosti v těchto zemích nižších hodnot, než je tomu v zemích západní nebo severní Evropy. Úhrnná plodnost na území České republiky se

2 Mladí lidé mají možnost volit si, ovšem otázkou zůstává, zda tak činí. Své sny a cíle musí neustále konfrontovat $\mathrm{s}$ tlakem médií a také sociálním tlakem ze strany společnosti, rodiny nebo svých vrstevníků. 
v době socialismu pohybovala až na výjimky nad hranicí dvou dětí. K postupnému poklesu úhrnné míry plodnosti pod hranici hodnoty dvě začalo docházet již před pádem socialismu a úhrnná plodnost postupně klesla až pod hodnoty jiných evropských zemí, ve kterých docházelo ke změnám reprodukčních strategií o několik desítek let dříve. Ze země, která byla charakteristická vysokou mírou úhrnné plodnosti, se stala země s nejnižší mírou v rámci celé Evropy a světa (Hašková 2008, Sobotka a kol. 2008). Lidé v reprodukčním věku začali přijímat nové strategie aplikovatelné na současné tržně ekonomické prostředí. Mladí lidé začali odkládat narození prvního dítěte do pozdějšího věku a současně došlo ke zvýšení podílu bezdětných. Zatímco průměrný věk ženy při narození prvního dítěte byl v 80 . letech 20 . století zhruba 22 let, v roce 2010 dosáhl 27,6 let (Pohyb obyvatelstva). Za posledních dvacet let se průměrný věk žen při narození prvního dítěte zvýšil o více než pět roků.

Tento posun potvrzují i data z našeho výzkumu. Mladí lidé ve věku od 27 do 29 let v našem vzorku by chtěli mít první dítě v průměru v 31,5 letech. Hodnoty odhadovaného průměrného věku se v našem vzorku statisticky významně liší podle pohlaví a dosaženého vzdělání. Muži chtějí mít první dítě později než ženy. Negativní korelaci s odhadovaným věkem jsme zjistili také u dosaženého vzdělání. Vysokoškolsky vzdělaní lidé v našem vzorku chtějí mít první dítě dříve (30,9 let) než mladí lidé se středoškolským vzděláním bez maturity (32,1 let). Sobotka a kol. (2008: 423) však dokládá na datech z roku 2001, že jsou to právě ženy se středoškolským vzděláním, které se typicky stávají matkami ve věku od 26 do 28 let, zatímco vysokoškolsky vzdělané ženy mají své první dítě až okolo 30 let věku. Podle van de Kaa (2001: 318) obecně platí, že ženy s nižší úrovní vzdělání mají děti dříve než ženy s vyšším vzděláním.

U mladých lidí dochází současně s odkládáním početí prvního dítěte do pozdějšího věku také ke změně reprodukčních strategií v otázce počtu narozených dětí. Někteří v důsledku odkládání narození dítěte nestihnou dítě počít nebo se uchylují (at' už dobrovolně nebo nedobrovolně) ke strategii bezdětnosti. Zatímco bezdětnost v době socialismu nepřekročila 5 až 7 \% (Rabušic 2001, Rychtaříková 2003, Hašková 2005, Juříčková 2005), současné prognózy počítají s dosažením západních hodnot - s podílem více než $20 \%$ celoživotně bezdětných žen ${ }^{3}$ (Coleman 1998, Rychtaříková 2003). Reprodukční strategie směřují ještě k trendu jedináčkovství a opouští zakládání větších rodin (Paloncyová 2002a, Rabušic, Chromková Manea 2007, Sobotka a kol. 2008).

Pokles míry úhrnné plodnosti $\mathrm{v}$ postsocialistických zemích je odrazem internalizace západních, individualistických hodnot a sociálních, kulturních, ekonomických a politických změn. Došlo ke změně konstrukce reality - mladí lidé si chtějí napřed užít svého života, stát se nezávislými a něco ve společnosti dokázat, a až následně přemýšlet o založení rodiny (Paloncyová 2002b). Život ve společnosti je podle autorky pravděpodobně úspěšnější bez rodinných závazků. Za dob socialismu bylo výhodné zakládat rodinu v nižším věku, jelikož mladí rodiče mohli očekávat materiální podporu od svých rodičů a pronatalitně nastavených

3 Vysoký a stále se zvyšující podíl celoživotně bezdětných lidí Hašková (2008) vysvětluje institucionálními a strukturálními důvody a změnou hodnot. Vzrůstá preference celoživotní bezdětnosti nad rodičovstvím. Permanentní bezdětnost se stává životním stylem výrazné části mladé populace. 
politik. V moderní době se zdá být rozumnější a výhodnější založit rodinu později, až když je člověk ekonomicky zajištěný, má vhodné bytové podmínky a je na rodičovství připraven.

Zde vyvstává otázka, zda mladí Češi a Češky chtějí mít dítě nebo děti. Z výsledků řady výzkumů vyplývá, že založení rodiny a početí potomka představuje pro většinu české společnosti prioritu. Právě rodina a děti hrají v hodnotovém žebříčku lidí zcela zásadní roli a obojí se řadí na jeho nejvyšší příčky (Kučera 2000b, Kuchařová 2003, Šamanová 2006, Št’astná 2007). I přes akceptaci a internalizaci kapitalistického, individualistického hodnotového systému je tradiční hodnota dítěte a založení rodiny jedním $\mathrm{z}$ nejdůležitějších aspektů $\mathrm{v}$ životě většiny lidí.

Mladí lidé dotazovaní v našem výzkumu chtějí mít děti. Ve většině př́padů se ve svých odpovědích drželi ideálu rodiny - dvoudětného modelu. Pouze minimum respondentů konstatovalo, že by nechtělo mít ve svém životě žádné dítě. Mladým lidem ve věku od 27 do 29 let jsme položili dvě otázky vztahující se $\mathrm{k}$ jejich práním a plánům týkajícím se počtu dětí. První otázka „Kolik dětí byste při ideálních podmínkách chtěl(a) mít celkem?" se ptala na počet dětí, který by si respondenti přáli mít bez ohledu na jejich sociální nebo ekonomickou situaci (ideální počet dětí). Ve druhé otázce „Když vezmete v úvahu své současné poměry a možnou budoucí situaci, kolik détí byste chtěl(a) mít celkem? " již měli vzít respondenti v potaz svoje možné budoucí poměry a životní situaci ve vztahu k plánovanému počtu dětí (očekávaný počet dětí). V otázce zjišt'ující ideální počet dětí nejde o zjišt'ování plánovaného počtu dětí, ale spíše o měření ochoty stát se rodičem (Paloncyová 2002a: 14). Druhou otázku lze považovat za reprodukci plánovaného počtu dětí, avšak musíme si uvědomit, že tyto plány se nemusí nakonec respondentům podařit realizovat. ${ }^{4}$

Většina dotázaných mladých lidí by chtěla při ideálních $(61,4 \%)$ i reálných $(60,9 \%)$ podmínkách dosáhnout dvoudětného modelu, který v české populaci představuje normu již od dob socialismu (Sobotka a kol. 2008). Výsledky výzkumů provedených po roce 1989 dokumentují podobné počty at' už ideálního, nebo plánovaného počtů dětí (Kučera 2000a, Paloncyová 2002a, 2002b, Šalamounová a Šamanová 2004, Sobotka a kol. 2008). U dalších variant již docházelo $\mathrm{k}$ rozdílným odpovědím ve vztahu $\mathrm{k}$ jednotlivým otázkám. Při ideálních podmínkách by 22,6 \% mladých lidí chtělo tři a více dětí, ovšem po zvážení své současné nebo budoucí situace by chtělo tři a více dětí o 10 procentních bodů méně respondentů. Na otázku, jaký je plánovaný počet dětí, byl zjištěn vyšší podíl odpovědí u varianty „žádné“ nebo ,jedno dítě“ než u otázky zjišt’ující ideální počet dětí. Tyto výsledky odpovídají trendu přechodu české společnosti od početné rodiny (tř̌i a více dětí) $\mathrm{k}$ rodině s jedním

4 Van de Kaa (2001) upozorňuje v problematice odhadu ideálního a plánovaného počtu dětí na možná úskalí. Uváděné počty jsou pouhými odhady, které mohou podléhat současnému stavu (partnerskému, zdravotnímu, psychickému aj.), a také mohou být ovlivněny věkem respondentů. Uvedené údaje o počtech dětí se stávají realističtějšími se zvyšujícím se věkem a měly by být spíše využívány jako faktor ochoty mít děti. Podle názoru Haškové (2006: 23) a van Peer a Rabušice (2008) jsou počty plánovaných dětí a ideální počty dětí velmi slabým a nedostatečným nástrojem pro predikování reprodukčního chování mladých lidí, jelikož jsou zatíženy společensky vhodnými odpověd'mi. Většinou jsou tato dvě čísla nadhodnocena oproti konečným reálným číslům. Avšak van de Kaa (2001: 316) uvádí příklad zkoumání plánovaného počtu dětí v Nizozemí, ve kterém se výsledky př́liš nelišily od následné reality. 
dítětem (Paloncyová 2002a, Sobotka a kol. 2008). Vícedětné rodiny (tř̌i a více dětí) se stávají v dnešní době spíše neobvyklými.

Průměrné počty dětí uvedené respondenty v obou těchto otázkách se liší. Průměrný ideální počet dětí dosáhl hodnoty 2,1 dítěte. Požadavky mladých lidí v této věkové skupině se v tomto ohledu nijak výrazně neliší od názorů šíře věkově zastoupené populace v jiných výzkumech (Hamplová 2000, Kučera 2000a, Hašková 2005). Avšak při úvaze nad současnou nebo budoucí sociální a ekonomickou situací se našimi respondenty plánovaný průměrný počet dětí snížil na hodnotu 1,85 . Rozdíly v průměrných hodnotách plánovaných dětí se statisticky významně neliší podle pohlaví nebo velikosti sídla, ve kterém mladý člověk žije. ${ }^{5}$ Významně vyšší průměr počtu plánovaných dětí byl zjištěn u mladých rodičů oproti bezdětným respondentům a u mladých lidí, kteří se subjektivně identifikovali s chudými, oproti respondentům $\mathrm{z}$ bohatší vrstvy obyvatel. U odpovědí mladých lidí hlásících se k náboženské víré ${ }^{6}$ byl identifikován statisticky významně vyšší průměr počtu plánovaných dětí než u mužů a žen bez náboženského vyznání. Mladí lidé hlásící se k nějakému náboženskému vyznání plánují, že budou mít častěji tři a více dětí, zatímco variantu jednoho dítěte si připouštěli v menší míře než lidé bez křest’anské víry. Vliv náboženské víry na ideální počet dětí dokládají i jiné výzkumy (Ettlerová a Matějková 2004). Konečná fertilita je podle Sobotky a kol. (2008) vyšší právě u lidí vyznávajících katolickou náboženskou víru než u mužů a žen bez náboženské víry. Podle Nešporové (2005) souvisí rozdílné požadavky na počet dětí v samotné podstatě křest'anské víry. Ta uznává pouze manželský svazek muže a ženy, jehož jediným cílem má být plození potomků. Dítě je považováno za dar Boha a jediné štěstí rodičů.

Ve vztahu mezi plánovaným počtem dětí a dosaženým vzděláním ${ }^{7}$ byla zjištěna pozitivní korelace. Zatímco vysokoškolsky vzdělaní lidé (včetně vyššího odborného vzdělání) se častěji přiklánějí k možnosti dvou nebo tří a více dětí, mladí lidé ve věku od 27 do 29 let se středoškolským vzděláním bez maturity častěji volili variantu jednoho nebo žádného dítěte. U respondentů se středoškolským vzděláním bez maturity se dvakrát častěji setkáme s plánem mít pouze jedno dítě $(31,5 \%)$, než je tomu u vysokoškolsky vzdělaných respondentů $(15,2 \%)$. Podobně je tomu také u plánované bezdětnosti $-3,1 \%$ vysokoškolsky vzdělaných respondentů oproti 5,9 \% respondentů se středoškolským vzděláním bez maturity. Platí, že čím vyšší úrovně vzdělání respondenti dosáhli, tím vyšší počet dětí se domnívají, že budou reálně mít (van de Kaa 2001, van Peer a Rabušic 2008). Tyto rozdílné hodnoty odpovědí lze vysvětlit tím, že lidé s vyšší úrovní vzdělání mohou podle našeho názoru pocit'ovat větší tlak společnosti na své rodičovské plány a také se mohou domnívat, že díky svému vzdělání budou schopni finančně zabezpečit více dětí. Mohou předpokládat, že jejich ekonomická a sociální situace dostatečně vyhovuje nebo bude vyhovovat zabezpečení vyššího počtu dětí,

5 Test statistické významnosti na hladině $95 \%$ byl proveden metodou T-testu (Independent Samples T-test). Tento test byl využit i u následujících intepretací v rámci této kapitoly.

6 Podíl věřících je v našem vzorku $23,2 \%$, nevěřících nebo přesvědčených ateistů $54 \%$ respondentů. Ostatní respondenti nechtěli na tuto otázku odpovědět nebo nevěděli odpověd'.

7 Distribuce vzorku podle nejvyššího dosaženého vzdělání je následující: 30,3 \% respondentů se základním vzděláním, vyučením nebo středoškolským vzděláním bez maturity, 38,6 \% respondentů se středoškolským vzděláním s maturitou a 31,1 \% respondentů s vysokoškolským vzděláním nebo vyšším odborným vzděláním. 
než je tomu u respondentů s nižšími úrovněmi vzdělání, již nemusí svoji situaci pokládat za stabilní a progresivní. Jsou to však právě vysokoškolsky vzdělané ženy, kterým se nakonec narodí méně dětí (Seccombe 1991, Sobotka a kol. 2008). Průměrný počet dětí u mladých žen se základním vzděláním narozených kolem roku 1960 je výrazně vyšší (2,26 dítěte) než u vysokoškolsky vzdělaných žen (1,73 dítěte) (Sobotka a kol. 2008). Přestože se mladí lidé $\mathrm{s}$ vysokoškolským vzděláním v reprodukčních záměrech projevují spíše konzervativně, jejich plány jim nakonec nevychází. Predikuje se, že se zvyšující se úrovní vzdělání populace Evropy bude docházet k dalšímu snížení fertility (van de Kaa 2001, McDonald 2002). ${ }^{8}$

\section{Dưvody odkládání narození dítěte}

Fenoménem současných reprodukčních strategií mladých lidí je odkládání početí prvního dítěte do pozdějšího věku. Důvody nalezneme jak na individuální, tak na makroekonomické úrovni. Žít sám bez dítěte má své výhody - nezávislost, možnosti cestování, vzdělávání, profesního růstu, a také více času na zábavu s přáteli, na své záliby a volnočasové aktivity. Mladí lidé také využívají šanci dosáhnout vyšší úrovně vzdělání a následně se uplatnit na trhu práce pro získání ekonomické nezávislosti. Užívají si svobodný život a hledají partnera vhodného pro společný rodinný život. Ekonomická situace mladých a jejich pozdější odchod z domu rodičů jsou dalšími důvody oddalování založení vlastní domácnosti s dítětem.

Zhruba čtvrtina mladých lidí ve vzorku měla v době dotazování alespoň jedno dítě a pouze malá část $\mathrm{z}$ dotázaných mužů a žen rozhodně nebo spíše plánovala mít v následujících dvanácti měsících (další) dítě. $\mathrm{V}$ rámci této podkapitoly nás bude zajímat, jaké faktory ovlivňují rozhodování mladých mužů a žen oddálit početí prvního nebo dalšího dítěte. Pro zachycení důvodů odkládání početí (dalšího) dítěte jsme se mladých lidí ve věku od 27 do 29 let zeptali na otázku: Jaké jsou Vaše důvody pro odkládání narození (dalšiho) dítěte? Respondentům bylo nabídnuto sedm možných důvodů, přičemž ke každému se vyjadřovali na škále hodnot 1 až 5 , kde 1 = rozhodně je důvodem a 5 = rozhodně není důvodem. Tuto otázku jsme položili těm našim respondentům, kteří konstatovali, že v následujících dvanácti měsících rozhodně nebo spíše neplánují početí (dalšího) dítěte. ${ }^{9}$

Dotázaní muži a ženy se shodli na tom, že dvěma hlavními důvody, kvůli kterým odkládají narození dítěte do vyššího věku, jsou nevyhovující ekonomická a bytová situace. Více než polovina mladých respondentů ve věku od 27 do 29 let si uvědomuje, že s narozením dítěte prrijdou pro rodiče zejména finanční náklady na péči o něj. Tito respondenti se ještě ve svém věku necítí být natolik finančně zajištění, aby mohli založit rodinu s dítětem. Námi zjištěné skutečnosti potvrzují výsledky mnohých výzkumů (Mareš 2002, Paloncyová 2002b,

$8 \quad$ Van de Kaa (2001: 319) upozorňuje na úskalí odhadu počtu plánovaných dětí v závislosti na vzdělání respondenta. Přestože jsou vysokoškoláci lépe vzdělaní, neznamená to, že budou vynášet lepší soudy o své budoucnosti. Přestože plánují mít více dětí, právě kvůli tomu, že studují vysokou školu a budují svoji kariéru, nestíhají své plány uskutečnit nebo jich nakonec nechtějí dosáhnout.

9 Otázky vztahující se $\mathrm{k}$ důvodům odkládání početí dítěte byly pokládány pouze těm respondentům, kteří v následujících dvanácti měsících neplánují mít dítě. $\mathrm{V}$ rámci této kapitoly jsme nepracovali s 16,4 \% respondentů, kteří uvedli, že v následujících dvanácti měsících plánují mít dítě. 
Mareš 2004, Šalamounová a Šamanová 2004, Hašková 2008), podle kterých je právě nedostatek finančních zdrojů jedním z nejčastějších důvodů, kvůli kterému lidé odkládají početí dítěte.

Druhý výrazný faktor ovlivňující oddalování početí dítěte představuje bytová situace, která je neodmyslitelně spojena s nedostatečnými financemi. Mladí lidé nedisponují takovými bytovými prostory, které by byly podle jejich názoru vhodné pro život s dítětem. Spojení důvodu nevyhovující ekonomické a bytové situace značí, že mladí lidé nemusí mít také dostatek financí na pořízení si vlastního bydlení nebo takových prostor, které by byly vhodné pro život $s$ dítětem. Ekonomický faktor společně s bytovými podmínkami jsou pro mladé lidi nejdůležitějšími důvody, proč v současné době odkládají početí dítěte (Ettlerová a Matějková 2004, Hašková 2008). Pokud se finanční situace mladých lidí nezlepší, je možné předpokládat, že počet narozených dětí se zcela jistě nepřiblíží $\mathrm{k}$ ideálním počtưm dětí. K podobným výsledkům došel také výzkum Eurobarometr v roce 2002, který proběhl v členských zemích (EU 15) a kandidátských zemích na vstup do EU. Zatímco pro respondenty z nových členských zemí představovaly klíčové determinanty v rozhodování a plánování rodiny zpravidla ekonomická a bytová situace, tak pro obyvatele zemí EU 15 to byl zdravotní stav, partnerská situace a změna reprodukčních preferencí (Hašková 2005, 2008). Výrazný důraz na ekonomickou a bytovou situaci u nově přistoupených zemí potvrdil o čtyři roky později provedený výzkum Eurobarometr 2006 (Testa 2006).

Dalšími dvěma výraznými determinantami odkládání reprodukce do pozdějšího věku, které vybrala téměř polovina mladých lidí ve věku od 27 do 29 let, jsou nedostatečná psychická připravenost na roli rodiče a neexistence vhodného partnera nebo partnerky, se kterou by chtěli počít a vychovávat dítě. Již menší podíl mladých mužů a žen konstatoval, že důvod pro odkládání početí dítěte do pozdějšího věku spočívá v jejich neochotě omezovat rozvoj své profesní kariéry a trávení svého volného času, který chtějí věnovat svým zálibám a zájmům.

Rodiče ve věku od 27 do 29 let v našem vzorku se domnívají, že pro odkládání početí dalšího dítěte jsou nejvýraznější ekonomické důvody. U dalších odůvodnění nepřekračoval podíl souhlasných odpovědí $30 \%$. Skupina bezdětných mladých mužů a žen se s rodiči shodla na nejvýznamnějším faktoru ovlivňujícím jejich reprodukční strategie - ekonomické situaci. Bezdětní však vyzdvihli další tři pro ně významné determinanty - nevyhovující bytové podmínky, nedostatečnou psychickou připravenost na narození dítěte a neexistenci vhodného partnera nebo partnerky pro početí dítěte.

Pro zjednodušení a prohloubení našeho argumentu byla provedena faktorová analýza, kterou byly vytvořeny tři faktory - Hodnoty, Ekonomická situace a Partner. Hodnoty faktorových zátěží a proměnné spadající do jednotlivých faktorů jsou uvedeny v následující tabulce 1.

Faktor 1 nazvaný Hodnoty odkazuje na individualistické hodnoty mladých lidí vztahující se k jejich práci, trávení volného času a psychické dospělosti. Druhý faktor Ekonomická situace odkazuje na situaci mladých lidí v otázce financí a bytových možností a prostor vhodných pro dítě. Faktor 3 s názvem Partner odkazuje k zázemí v partnerovi nebo partnerce v otázce reprodukčních strategií. 
Tabulka 1: Faktory ovlivňující odkládání početí (dalšího) dítěte do pozdějšího věku

\begin{tabular}{|l|c|c|c|}
\hline & $\begin{array}{c}\text { Faktor 1 } \\
\text { Hodnoty }\end{array}$ & $\begin{array}{c}\text { Faktor 2 } \\
\text { Ekonomická situace }\end{array}$ & $\begin{array}{c}\text { Faktor 3 } \\
\text { Partner }\end{array}$ \\
\hline $\begin{array}{l}\text { Neochota omezit svůj volný čas } \\
\text { věnovaný svým zájmům }\end{array}$ & $\mathbf{0 , 8 7 7}$ & 0,128 & 0,244 \\
\hline Neochota omezit svo̊j rozvoj v zaměstnání & $\mathbf{0 , 8 6 4}$ & 0,172 & - \\
\hline Psychická nepřipravenost na rodičovství & $\mathbf{0 , 6 9 0}$ & 0,281 & 0,233 \\
\hline Nevyhovující ekonomická situace & 0,239 & $\mathbf{0 , 8 6 3}$ & - \\
\hline Nevyhovující bytová situace & 0,165 & $\mathbf{0 , 8 3 9}$ & 0,223 \\
\hline Partner/ka nechce dítě & 0,166 & - & $\mathbf{0 , 7 9 3}$ \\
\hline Neexistence vhodné/ho partnera/ky & 0,173 & 0,134 & $\mathbf{0 , 7 4 3}$ \\
\hline
\end{tabular}

Zdroj: PARO 2010, věková skupina 27-29 let.

Poznámka: Do faktorové analýzy vstoupilo sedm z devíti proměnných. Proměnné „Je nutné mít zajištěno hlídání dítěte" a „Musím být se svým partnerem/partnerkou zajedno v otázce rozdělení domácích prací". Ve faktorové analýze byla použita metoda Varimax rotace s určením tří faktorů. Tyto faktory vysvětlují $72,6 \%$ celkového rozptylu, přičemž faktor 1 vysvětluje 30,5 \%, faktor 2 vysvětluje 22,8 \% a faktor 3 vysvětluje 19,3\% celkového rozptylu. $\mathrm{KMO}=0,773$.

Při analýze vztahu mezi sociodemografickými charakteristikami respondentů a vlivem faktorů jsem zjistila, že faktor Hodnoty spíše ovlivňuje reprodukční záměry bezdětných respondentů bez náboženského vyznání, mladých lidí žijících v domácnosti se svými rodiči bez manželského svazku se svým partnerem nebo partnerkou. Individualistické hodnoty vztahující se k profesnímu a soukromému životu ovlivňují odkládání narození dítěte u mladých lidí, kteří nemají vážný vztah. Nebyl prokázán vztah mezi tímto faktorem a úrovní dosaženého vzdělání. Faktor Hodnoty tedy ovlivňuje reprodukční strategie mladých lidí spíše bez partnerských nebo rodičovských závazků, kteří ještě nezaložili vlastní domácnost. Tito mladí lidé v současné době ještě nemusí nutně přemýšlet nad založením rodiny s dítětem. Jejich cílem spíše bude nalezení partnera nebo partnerky pro vážný vztah a vybudování vlastní domácnosti. Je pravděpodobné, že v důsledku své současné životní situace odpovídali tak, jako by dítě představovalo překážku v dosažení těchto cílů.

Př́ijmová a bytová situace mladší generace jsou obecně v dnešní době horší, než bývaly u starších generací v době, kdy tyto zakládaly rodiny (Hašková 2008: 77). Nepř́znivější finanční a bytové podmínky jsou doplněny vzrůstajícími př́mými a nepřímými výdaji na dítě. Současně vzrůstají požadavky mladých lidí na př́ijem a bytové prostory. Ekonomické a bytové podmínky byly ve výzkumu Haškové (2008) důležité pro mladé lidi bez partnerského vztahu, bezdětné a mladé lidí s vyšší úrovní vzdělání. Faktor Ekonomická situace ovlivňuje v porovnání s výsledky popsanými Haškovou (2008) pouze skupinu bezdětných mladých lidí, u proměnných vzdělání a partnerský vztah nebyly zjištěny významné korelace. Faktor Ekonomická situace je také významný pro muže a ženy žijící ve společné domácnosti s rodiči a pro jedince žijící v nesezdaném soužití. Ekonomická situace společně s nevyhovujícím bydlením výrazně ovlivňuje rozhodování o početí dítěte u mladých lidí, kteří se subjektivně označili za ekonomicky chudší. Finanční a bytová situace rodiny se dotýkají zejména chudších rodin, které nemají tolik možností výběru vhodného bydlení (Benokraitis 2002). Prostorově větší bydlení je drahé a v menším, ovšem finančně přijatelném bydlení je téměř nemožné zakládat rodinu nebo ji zvětšovat. 
Třetí faktor vyjadřující ne/existenci zázemí partnerského života $\mathrm{v}$ otázce reprodukce ovlivňuje zejména respondenty bez náboženské víry, muže a mladé lidi bez vážného vztahu sdílející se svými rodiči společnou domácnost. Tento faktor výrazně ovlivňuje oddalování reprodukce u chudých respondentů a mladých lidí s nižší úrovní vzdělání.

\section{Změny očekávané s narozením dítěte}

V předchozí kapitole byly analyzovány determinanty odkládání narození dítěte do pozdějšího věku u mladých mužů a žen. Zjišt'ovala jsem, proč jsou mladí lidé v tomto věku stále bezdětní a odkládají početí dítěte do pozdějšího věku. V této části textu se zaměřím na očekávání spojená s prŕíchodem dítěte. Mladí lidé mají představy o tom, jakých cílů by chtěli před příchodem dítěte dosáhnout. Jaké změny ve svém soukromém a veřejném životě ale očekávají s př́ichodem dítěte? Respondenti se měli zamyslet nad tím, o jaké možnosti v rámci svého profesního a soukromého života přijdou, k jakým omezením v jejich životě dojde po narození dítěte a jaká negativa s sebou dítě přinese. I v rámci této podkapitoly jsem sledovala rozdíly v odpovědích ve vztahu k vybraným sociodemografickým znakům.

Mladí lidé mají při přemýšlení o dítěti a při jeho plánování představy o tom, co se $\mathrm{s}$ prríchodem dítěte $\mathrm{v}$ jejich životě změní - tedy jaké budou náklady (nejen finanční) spojené s narozením a výchovou dítěte. Většina mladých lidí ve věku od 27 do 29 let souhlasí s tvrzením, že narození dítěte bude znamenat zvýšené finanční náklady. Dítě již nepředstavuje pro rodiče ekonomickou výhodu, jeho hodnota se změnila. Jsou to právě finanční prostředky, které v současné době formují velikost rodiny (Benokraitis 2002). Rozhodování o počtu dětí závisí z velké části na rodinném rozpočtu, tedy na tom, kolik dětí si mladí lidé mohou dovolit. ${ }^{10} \mathrm{~V}$ současných moderních společnostech, ve kterých se narození dítěte plánuje, musí být rodiče na příchod dítěte ekonomicky připraveni, jelikož s jeho narozením jim vzniknou nové investice, které prretrvávají několik let, možná i desítek let. Finanční nezajištění mladých se proto jeví jako jeden z nejvýznamnějších důvodů pro odsouvání narození (dalšího) dítěte do pozdějšího věku (viz předchozí kapitola).

Muži a ženy ve věku 27 až 29 let si jsou vědomi, že náklady spojené s narozením a následnou výchovou dítěte budou značné. Nebude pro ně možné si po narození dítěte $\mathrm{z}$ finančních důvodů tolik dovolit jako před jeho př́íchodem (viz graf 1). Pouze 12,5\% dotázaných respondentů $\mathrm{v}$ této věkové skupině si myslí, že dítě nebude mít negativní dopad na finanční situaci rodiny. Rozdíly v odpovědích mužů a žen, rodičů a bezdětných v otázce finanční náročnosti a výdajů spojených s rodičovstvím nejsou statisticky významné ${ }^{11}$

10 Tento jev dokazují i rozdílné průměrné hodnoty a rozložení odpovědí v otázkách týkajících se ideálního a plánovaného počtu dětí. Benokraitis (2002: 246) popisuje vliv ekonomické situace rodiny na dvou výzkumech prováděných v USA v roce 1997. V rámci jednoho výzkumu $31 \%$ respondentů uvedlo, že rodina $\mathrm{s}$ třemi a více dětmi by byla ideální. Ovšem v druhém výzkumu se vyjádřilo $53 \%$ respondentů, že by chtěli mít tři a více dětí, pokud by finanční stránka nebyla problémem.

11 Test statistické významnosti na hladině $95 \%$ byl proveden metodou T-testu (Independent Samples T-test). Tento test byl využit i u následujících intepretací v rámci této kapitoly. 
- všechny skupiny vnímají finanční náročnost dítěte podobně. Významné rozdíly byly zjištěny mezi respondenty, kteří se identifikovali jako chudí, oproti jedincům, kteří se subjektivně označili za bohaté. Chudší ženy a muži si jsou více vědomi finanční náročnosti spojené s narozením dítěte. Ekonomické náklady spojené s dítětem si také více uvědomují vysokoškolsky vzdělaní lidé oproti mužům a ženám se středoškolským vzděláním bez maturity. Mladí lidé se na finanční náročnost dívají rozdílně také podle počtu plánovaných potomků. Ti, kteří s ohledem na svoji situaci chtějí mít pouze jedno dítě, očekávají zatížení rodinného rozpočtu výrazněji než mladí lidé přející si tři nebo více dětí.

Graf 1: Postoje mladých lidí k rodičovství v otázce financí, náročnosti výchovy, volného času, svobody a pracovní kariéry

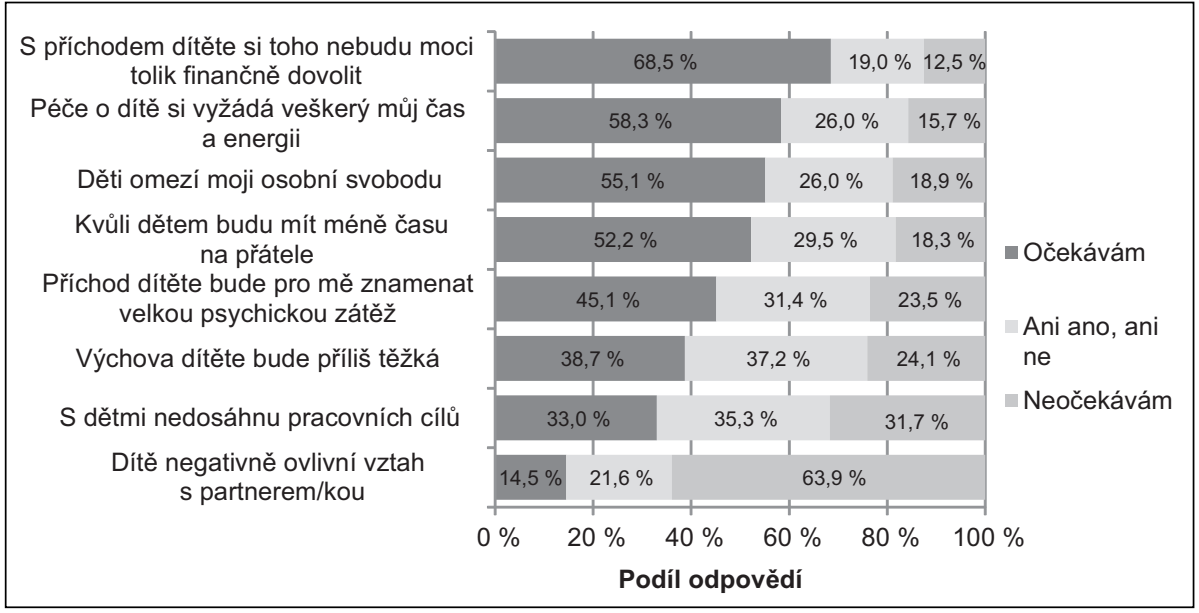

Otázku finanční náročnosti dítěte si uvědomují spíše chudší, vysokoškolsky vzdělaní lidé přející si jedináčka. Zjištění potvrzují jiné české výzkumy. Podle Kuchařové (2003) rodina pocítí po narození dítěte negativní dopady na ekonomickou situaci domácnosti. Rodiče současně očekávají, že dítě nebude na jejich péči a financích závislé pouze v průběhu prvních let svého života, ale minimálně do své plnoletosti. Pro rodiče znamená výchova dítěte velké finanční náklady a nízké a nejisté zisky v dlouhodobé perspektivě (Možný, Pakosta a Přidalová 2008). Rodiče si uvědomují, že jeden z nich bude muset kvůli péči o potomka odejít na několik let ze svého zaměstnání, čímž rodina přijde o jeden plat, jelikož rodičovský př́spěvek pokryje tuto ztrátu pouze z části.

Přímé náklady a investice do rodičovství spočívající v materiálních (finančních) výdajích jsou doplněny také nepř́mými náklady (Coleman 1998: 23). Mladí lidé očekávají, že do rodičovství budou muset investovat nejenom peníze, ale také svůj volný čas a energii. Neprŕmé náklady tedy spočívají ve ztrátě př́ležitostí jednoho nebo obou rodičů. Ti jsou obvykle nuceni obětovat své možnosti vzdělání, postupu v zaměstnání, rozvoje svých schopností a dovedností a také obětovat svoji svobodu a volný čas. 
$\mathrm{V}$ rámci našeho výzkumu jsme se ptali mladých lidí na jejich názory na pět potenciálních nepř́mých nákladů na péči o dítě. Respondenti měli stanovit, jak moc rodičovské povinnosti ovlivní jejich trávení volného času a výdej energie, jejich osobní svobodu, jejich čas strávený s př́teli, jak ovlivní jejich psychiku, a současně zda rodičovství bude znamenat překážku v dosažení pracovních cílů nebo v harmonickém partnerském soužití.

$\mathrm{Z}$ analýzy dat vyplývá, že mladí lidé kromě př́mých výdajů očekávají s narozením dítěte také náklady nepřímé. Více než polovina respondentů se domnívá, že narození dítěte negativně ovlivní způsob trávení jejich volného času a množství času, který by mohli věnovat pouze sobě a svým zálibám, a současně dojde k omezení jejich osobní svobody. Domnívají se, že rozvoj jejich aktivit a nezávislosti bude omezen (to potvrzují i dřívější výzkumy Kuchařová 2003, Šamanová 2006).

Vydání veškerého svého volného času a energie častěji očekávají mladé ženy než muži. Tento rozdíl může být ovlivněn přetrváváním stereotypního rozdělení genderových rolí, podle kterého většina žen přebírá hlavní zodpovědnost za péči o dítě ihned po jeho narození. V důsledku nepřetržité péče ztrácejí ženy zpravidla možnost uspořádat si svůj volný čas tak, jak by chtěly. Všechen svůj čas musí podřídit potřebám dítěte. Výraznější omezení volného času a vydání energie na péči o dítě si uvědomují spíše mladí lidé plánující pouze jedináčka než respondenti plánující tři a více děti. Tento rozdíl může být interpretován tak, že muži a ženy si přejí pouze jedno dítě právě kvůli obavě z omezení svého času a z výdeje energie. Významné rozdíly nebyly identifikovány mezi mladými lidmi s vysokoškolským vzděláním a středoškolsky vzdělanými lidmi bez maturity, mezi rodiči a bezdětnými ani mezi těmi, kteři v následujících dvanácti měsících plánují mít dítě, a těmi, kdo dítě neplánují.

Péče o dítě a čas věnovaný jen jemu negativně ovlivňuje osobní nezávislost rodičů (Kuchařová 2003, Št’astná 2007). Rodiče na sebe přebírají zodpovědnost za své dítě a musí plnit své rodičovské povinnosti. Zatímco výzkumy provedené v 90. letech 20. století v České republice zjistily, že každá třetí žena považovala dítě za př́liš velké omezení svobody rodičů (Kučera 2000a: 25), v roce 2006 zastávalo téměř 80 \% žen názor, že dítě omezuje život lidí v tom, co by chtěli dělat, nebo v tom, kam by chtěli jít (Možný, Pakosta a Přidalová 2008). Statisticky významné rozdíly v odpovědích mezi muži a ženami však v našem vzorku zjištěny nebyly. Významný rozdíl v průměrných hodnotách odpovědí byl zjištěn mezi vysokoškolsky vzdělanými mladými lidmi a respondenty se středoškolským vzděláním bez maturity. Větší omezení osobní svobody vnímají vysokoškoláci a také mladí lidé neplánující v následujícím roce dítě oproti těm, kteři jej plánují. Mladí muži a ženy, kteří mají v plánu v následujících dvanácti měsících počít dítě, jsou již zřejmě vyrovnaní s možnými omezeními, zatímco ti, co dítě neplánují, se tak mohli rozhodnout právě kvůli neochotě omezovat svoji svobodu. Současně větší omezení očekávají spíše mladí lidé plánující pouze jedno dítě než respondenti, kteří ve své odpovědi uvedli tři a více dětí. Tento výsledek je možné interpretovat tak, že respondenti plánují pouze jedno dítě právě kvůli vyšší míře negativních očekávání. Ti, kteři plánují vyšší počet dětí, mohou mít odlišné představy o náročnosti výchovy. Mohou se domnívat, že péče o dítě nebude natolik náročná, proto se přiklánějí k vyššímu počtu dětí.

S předešlými dvěma očekáváními (omezení volného času a osobní svobody) je spjato také očekávání nedostatku času na své přátele a známé. Mezi většinou zkoumaných skupin nebyly zjištěny žádné významné rozdíly v odpovědích. Možná omezení vnímají opět více 
vysokoškolsky vzdělaní lidé, kteří se oproti středoškolsky vzdělaným lidem bez maturity častěji přikláněli ke stanovisku, že s příchodem dítěte již nebudou mít tolik času na své přátele.

Třetina mladých lidí odpověděla, že $\mathrm{s}$ dítětem nedosáhnou svých pracovních cílů. Rozdíly v odpovědích mužů a žen se významně lišily. Ženy si více než muži uvědomovaly možné omezení svého profesního růstu $\mathrm{v}$ důsledku narození dítěte. Tyto rozdíly mohou být opět projevem reprodukce stereotypního rozdělení genderových rolí v moderních společnostech. Ženy jsou ve většině př́ípadů těmi, kdo narozením dítěte ztratí (Seccombe 1991, Bongaarts 2001, Hašková 2005). Většina z nich musí odejít ze svého zaměstnání a strávit dobu mateřské a posléze rodičovské dovolené s dítětem doma (Maříková a Radimská 2003, Tomešová Bartáková 2010). Odchází z trhu práce zpravidla v době, kdy by mohly rychle postupovat $\mathrm{v}$ zaměstnanecké kariéře. Odchodem na mateřskou a posléze rodičovskou dovolenou se zvyšují nepř́imé výdaje na dítě, které snižují možnost kariérního růstu. Tím, že po narození dítěte přetrvává stereotypní rozdělení rolí, není profesní růst mužů dětmi výrazně ovlivňován (Št’astná 2007). Otcové mohou i po narození dítěte nadále pokračovat v kariéře. U mužů tedy v období po narození dítěte dochází ke zvyšování osobních př́ijmů v rámci postupu v zaměstnání, zatímco ženám odcházejícím na mateřskou a následně rodičovskou dovolenou př́ijmy výrazně klesají. Lze tedy říci, že se reprodukce české společnosti odehrává zejména na „účet“ žen (Hašková 2005). Z tohoto důvodu muži nemusí pocit’ovat tak výrazný konflikt mezi rodičovstvím a svojí profesní kariérou.

Překvapivé výsledky přinesl výzkum Rodina 2001, podle kterého by tři čtvrtiny mladých lidí uvažovaly o možnosti odchodu muže na rodičovskou dovolenou, kdyby žena vydělávala výrazně více než muž (Paloncyová 2002a: 15). Většina žen však stále očekává, že to budou právě ony, jejichž pracovní kariéra, volný čas a osobní svoboda budou omezeny. Pod vlivem sociálního tlaku na sebe přebírají zodpovědnost za péči a výchovu dítěte. Nastavení trhu práce nahrává nejen mužům, ale také bezdětným lidem, kteří nepřeruší svůj pracovní proces, čímž si zvyšují potenciál postupu. Kromě žen častěji očekávají s př́íchodem dítěte nedosažení profesních cílů také chudší lidé oproti bohatším a ti, kteří plánují mít jedno dítě, oproti mladým lidem, kteří by chtěli mít tři a více dětí. Ženy si uvědomují, že budou muset přerušit svoji profesní kariéru, chudí pocítí ekonomické náklady na dítě a chybějící jeden př́ijem v domácnosti a lidé plánující pouze jedno dítě chtějí zmírnit míru negativních očekávání právě tím, že budou mít pouze jedno dítě. Některá teoretická východiska poukázala na možnou pozitivní korelaci mezi úrovní vzdělání a výší očekávaných výdajů na dítě v otázce šancí (Seccombe 1991, Lesthaeghe a Moors 2000). V rámci našeho vzorku však statisticky významné rozdíly v odpovědích žen s nižší a vyšší úrovní dosaženého vzdělání nebyly zjištěny.

Péče o potomka má vliv také na emocionální stránku života mladých rodičů. Rodičovství s sebou obvykle přináší nejen emoční př́nosy ve formě štěstí, radosti a spokojenosti, ale také emocionální výdaje. Téměř polovina respondentů se domnívá, že péče o dítě bude velkou psychickou zátěží. Lidé si obecně uvědomují velké emoční vypětí spojené s narozením a výchovou dítěte (Langdridge, Sheeran a Connolly 2005). Rodiče mají obavy z toho, že udělají něco špatně nebo že nebudou vědět, co dělat. Po narození potomka již nebudou zodpovědní jen sami za sebe, ale budou se muset o dítě starat a budou zodpovídat i za něj. Podle Arnolda a kol. (1975) se rodiče dennodenně obávají o zdraví dítěte, o jeho úspěšný život, uspokojování jeho potřeb a o to, aby jej dostatečně finančně zabezpečili. Významné rozdíly 
v odpovědích byly identifikovány pouze mezi skupinou mužů a žen plánujících pouze jedno dítě a těmi, kteří chtějí tři a více dětí. Potenciální rodiče jedináčkủ projevili výraznější obavy, že péče bude př́liš těžká a bude pro ně zároveň znamenat velkou psychickou zátěž.

Dítě může být vnímáno některými mladými lidmi jako element vstupující do vztahu dvou lidí s negativními následky pro jejich společné soužití. S narozením dítěte dojde k úbytku volného času, ve kterém se věnovali pouze jeden druhému (Langdridge, Sheeran a Connolly 2005). Mladí lidé předpokládají, že kvůli dítěti budou mít méně času na vlastní aktivity, na setkání s přáteli a sami na sebe. To může způsobit v partnerském vztahu problémy. Negativní ovlivnění partnerského vztahu předpokládali spíše mladí lidé neplánující v následujících dvanácti měsících dítě, lidé bez náboženského vyznání, lidé identifikující se jako přislušníci chudší skupiny obyvatel, lidé se středoškolským vzděláním bez maturity a respondenti přející si pouze jedno dítě.

V rámci tohoto textu byla analyzována pouze negativní očekávání mladých lidí spojená s narozením dítěte. Avšak je nutné si uvědomit, že existují i pozitivní očekávání, která, at' už ve větší nebo menší míře, motivují mladé lidí počít dítě. Benefity spojenými s narozením výchovou dítěte jsou např́iklad láska $\mathrm{k}$ dítěti, štěstí a radost $\mathrm{z}$ dítěte, utužení rodinných vztahů, pocit nesmrtelnosti nebo pokračování rodinného jména a tradic. Ty však nebyly z důvodu zaměření článku do analýzy zahrnuty.

\section{Závěr}

V současné době dochází ke zvyšování průměrného věku žen a mužů při narození prvního dítěte a současně vzrůstá podíl celoživotně bezdětných lidí. Debata o těchto demografických jevech je aktuální nejen v české společnosti, ale v rámci celé Evropy. Mladí lidé internalizující individualistické hodnoty se rozhodují, zda pro ně nebude ekonomicky a společensky výhodnější zůstat bezdětnými. Pokud se již rozhodnou pro variantu rodinného života s dítětem, plánují početí až na takovou dobu, kdy budou mít vhodné podmínky. Někteří mladí lidé se však v důsledku odkládání početí dítěte nakonec stanou také bezdětnými nebo jim není umožněno mít tolik dětí, kolik by chtěli mít.

V tomto článku jsem se zaměřila na zkoumání důvodů odkládání početí (dalšího) dítěte mladými lidmi ve věku od 27 do 29 let do pozdějšího věku z pohledu pohlaví respondentů, jejich dosaženého vzdělání, náboženské víry, bytových poměrů a dalších sociodemografických proměnných.

Výsledky analýzy dokládají, že mladí lidé odkládají narození dítěte zejména z důvodů své ekonomické a bytové situace. Největší podíl mladých mužů a žen také očekává, že s příchodem dítěte do rodiny se výrazně zvýší finanční výdaje. Dalším výrazným důvodem pro odkládání početí je nedostatečná psychická připravenost mladých lidí na rodičovství a současně neexistence vhodného partnera nebo partnerky, se kterým/kterou by chtěli mít dítě. Méně výraznými důvody jsou neochota přerušení pracovní kariéry a omezení svých volnočasových aktivit. Založení rodiny $\mathrm{v}$ moderní společnosti je především z materiálního hlediska, $\mathrm{z}$ hlediska seberealizace mimo rodinu a $\mathrm{z}$ hlediska časových nákladů vždy ztrátové (Paloncyová 2002b). 
Kromě př́mých finančních nákladů mladí muži a ženy často očekávají, že s narozením dítěte budou muset veškerou energii věnovat péči o dítě, budou muset omezit svoji osobní svobodu a svůj volný čas, který před narozením mohli věnovat svým zálibám. Více než třetina respondentů také očekává, že péče o dítě bude velmi psychicky náročná a nedosáhnou kvůli ní svých pracovních cílů.

Z výsledků analýzy vyplývá, že mladé lidi bez vážného vztahu nebo žijící v nesezdaném soužití s partnerem nebo partnerkou v rozhodování a reprodukčních strategiích výrazně ovlivňuje faktor Hodnoty. Ekonomická a bytová situace významněji ovlivňuje lidi žijící v nesezdaném soužití než mladé lidi žijící v manželském svazku. Mladí muži a ženy žijící ve společné domácnosti s rodiči jsou více ovlivňováni všemi třemi faktory. Odkládají početí dítěte do pozdějšího věku jak kvůli neochotě omezovat svůj rozvoj a volný čas a kvưli své psychické nevyspělosti, tak také kvůli nedostačující ekonomické a bytové situaci a nedostatečnému nebo neexistujícímu partnerskému zázemí.

Odpovědi mužů a žen byly ve většině otázek shodné - jejich názory na důvody odkládání početí dítěte a očekávání se př́liš nelišily. Ženy více než muži vyjadřovaly obavy z omezení svého volného času a nezbytnosti vydání své energie na péči o dítě. Současně se častěji domnívaly, že kvůli narození dítěte nedosáhnou již svých pracovních cílů.

$\mathrm{S}$ ohledem na vzdělání byly identifikovány odpovědi v rámci skupiny lidí se středoškolským vzděláním bez maturity a vysokoškolským vzděláním. Mladí muži a ženy s vysokoškolským vzděláním očekávali větší dopad narození dítěte na svoji ekonomickou situaci a větší omezení své osobní svobody a volného času na své prrátele a známé. Odpovědi lidí se středoškolským vzděláním bez maturity se významně neodlišovaly od odpovědí respondentů s vysokoškolským vzděláním ve vztahu k faktoru Hodnoty a Ekonomická situace. Muži a ženy se středoškolským vzděláním bez maturity však častěji pocit’ovali vliv faktoru Partner a očekávali větší negativní vliv dítěte na partnerský vztah.

Důvodem odkládání početí dítěte do vyššího věku je častěji u bezdětných respondentů než u rodičů nevyhovující ekonomická a bytová situace (faktor Ekonomická situace) a neochota omezit svoji činnost v zaměstnání a volném čase a také psychická nevyspělost (faktor Hodnoty). Ti respondenti, kteří neplánovali v následujících dvanácti měsících počít dítě, očekávali ve větší míře než mladí lidé plánující dítě, že narozením dítěte by došlo k omezení jejich osobní nezávislosti a současně že by dítě negativně ovlivnilo jejich partnerský vztah. Zajímavým výsledkem analýzy byly rozdíly v odpovědích na dané otázky podle počtu plánovaných dětí. V šesti ze sedmi otázek vztahujících se k očekáváním změn po narození dítěte respondenti plánující pouze jedno dítě uvedli častěji větší dopad na svůj život než mladí lidé plánující tři a více dětí.

Chudší respondenti si častěji uvědomovali vliv dítěte na svoji ekonomickou situaci, kterou pokládali společně s bytovou situací za významnější předpoklad než bohatí mladí lidé. Mladí muži a ženy z chudší vrstvy populace současně očekávali výraznější negativní vliv narození dítěte na svou finanční situaci, možnosti dosažení pracovních cílů a také partnerský vztah.

Analýzou dat bylo zjištěno, že v odůvodnění odkladu početí dítěte do pozdějšího věku hrají roli sociodemografické charakteristiky. Většina mladých lidí uvedla jako hlavní důvod posunování početí dítěte do vyššího věku nevyhovující finanční situaci. Odkládání početí 
dítěte kvůli tomuto důvodu je v závislosti na výsledcích našeho výzkumu charakterističtější pro člověka chudšího, bezdětného a vysokoškolsky vzdělaného, který žije ve společné domácnosti se svými rodiči a plánuje mít pouze jedno dítě. Je však možné očekávat, že tito lidé se budou chtít zprvu finančně osamostatnit, založit si vlastní domácnost a až následně budou zvažovat početí dítěte. Je jen otázkou, zda své reprodukční plány stihnout vyplnit.

\section{Literatura}

ARNOLD, Fred a kol. The Value of Children: A Cross-national Study. Introduction and Comparative Analysis. Honolulu: East-West Population Institute, 1975. 253 s. ISBN 0824803833.

BECK, Ulrich. Riziková společnost: na cestě $k$ jiné moderně. Praha: Sociologické nakladatelství, 2004. 431 s. ISBN 9788074190476.

BENOKRATIS, Nijole V. Marriages and Families. Changes, Choices, and Constraints. New Jersey: Prentice Hall, 2002. 570 s. ISBN 0130341770.

BONGAARTS, John. Fertility and Reproductive Preference in Post-Transitional Societies. In BULATAO, R. A., CASTERLINE, J. B. (eds.). Global Fertility Transition, New York: Population Council, 2001, s. 260-281. ISSN 00987921.

COLEMAN, David A. Reproduction and Survival in an Unknown World: What Drives Today's Industrial Populations, and to What Future? NIDI Hofstee Lecture Series no. 5. The Hague: NIDI, 1998. $41 \mathrm{s.}$ ISBN 90-70990-78-4.

Český statistický úřad. Pohyb obyvatelstva v Českých zemích 1920-2010 [online]. Dostupné na www: $<$ http://czso.cz/csu/redakce.nsf/i/obyvatelstvo_hu>

ETTLEROVÁ, Sylva; MATĚJKOVÁ, Barbora. Rodinné chováni a bytová situace mladé generace - souvislosti s partnerským, sňatkovým a natalitním chováním. Praha: VÚPS, 2004. $91 \mathrm{~s}$.

HAMPLOVÁ, Dana. 2000. Postoje k manželství a rodičovství. In FIALOVÁ, L. a kol. (eds.) Představy mladých lidí o manželství a rodičovství. Praha: Sociologické nakladatelství, 2000, s. 67-98. ISBN 8085850877.

HAŠKOVÁ, Hana. Reprodukční preference a bezdětnost v české společnosti ve světle kvantitativních dat [online]. 2005. Proměny. Dostupné na www: $<$ http://www.soc.cas.cz/download/365/reprodukcni\%20preference $\% 20 \mathrm{a} \% 20$ bezdetnost.pdf>

HAŠKOVÁ, Hana. Zkoumání bezdětnosti, jejího růstu a s ním souvisejících sociodemografických jevů v české společnosti v kontextu zemí střední a východní Evropy. Sociologické studie, 2006, roč. 6, č. 4, s. 22-58. ISBN 8073300923.

HAŠKOVÁ, Hana. Structural and Value Influences on the Entry into Parenthood in the Czech Republic. Demografia 2008, roč. 51, č. 5, s. 66-84. ISSN 0867-4841.

JUŘÍČKOVÁ, Lenka. Bezdětnost v České republice [online]. 2005. Demografie. Dostupná na www: $<\mathrm{http}: / /$ demografie.info/?cz_detail_clanku\&artclID $=118>$

KUČERA, Milan. Demografické chování mladých lidí v České republice, jeho sledování v průzkumech, hodnocení reálné situace a vnější vlivy. In FIALOVÁ, L. a kol. (eds.) Představy mladých lidí o manželství a rodičovství. Praha: Sociologické nakladatelství, 2000a, s. 7-28. ISBN 8085850877.

KUČERA, Milan. Představy o postavení sňatku a narození dětí v životní dráze mladých svobodných lidí. In FIALOVÁ, L. a kol. (eds.) Představy mladých lidí o manželství a rodičovství. Praha: Sociologické nakladatelství, 2000b, s. 45-66. ISBN 8085850877.

KUCHAŘOVÁ, Věra. 2003. Některé obsahové změny postojů k manželství a rodičovství. In MAREŠ, P., POTOČNÝ, T. (eds.) Modernizace a česká rodina. Brno: Barrister \& Principal, 2003, s. 189-204. ISBN 8086598616. 
LANGDRIDGE, Darren; SHEERAN, Paschal; CONNOLLY, Kevin. Understanding the Reasons for Parenthood. Journal of Reproductive and Infant Psychology, 2005, roč. 23, č. 2, s. 121-133. ISSN 0264-6838.

LESTHAEGHE, Ron; MOORS, Guy. 2000. Recent Trends in Fertility and Household Formation in the Industrialized World. Review of Population and Social Policy, 2000, č. 9, s. 121-170. ISSN 13462253.

MAREŠ, Petr. 2002. Hodnota dítěte. In PLAŇAVA, I., PILÁT, M. (eds.) Déti, mládež a rodiny v období transformace. Brno: Barrister \& Principal, 2002, s. 159-175. ISBN 8086598365.

MAREŠ, Petr. 2004. The Value of the Child. MAREŠ, P. a kol. (eds.). Society, Reproduction, and Contemporary Challenges. Brno: Barrister \& Principal, 2004, s. 61-77. ISBN 8086598675.

MAŘÍKOVÁ, Hana; RADIMSKÁ, Radka. Podpora využivání rodičovské dovolené muži. Praha: Sociologický ústav AV ČR, 2003. 103 s.

McDONALD, Peter. Low Fertility: Unifying the Theory and the Demography [online]. 2002. Dostupné na www: < http://digitalcollections.anu.edu.au/handle/1885/41437>

MOŽNÝ, Ivo; PAKOSTA, Petr; PŘIDALOVÁ, Marie. Declining Fertility in Europe, and, What Parenthood Means to the Czechs. Brno: Masaryk University, 2008. ISBN 9788021045545.

NEŠPOROVÁ, Olga. Rodina a rodičovství v křest’anství a islámu. Gender, rovné př́ležitosti, výzkum, 2005, roč. 6, č. 1, s. 3-7. ISSN 1213-0028.

PALONCYOVÁ, Jana. Změny české rodiny: mladá generace a demografický vývoj. Praha: VÚPS, 2002a. $49 \mathrm{~s}$.

PALONCYOVÁ, Jana. Rodinné chování mladé generace. Praha: VÚPS, 2002b. $100 \mathrm{~s}$.

RABUŠIC, Ladislav. Kde ty všechny děti jsou? Porodnost v sociologické perspektivě. Praha: Sociologické nakladatelství, 2001. 265 s. ISBN 8086429016.

RABUŠIC, Ladislav; CHROMKOVÁ MANEA, Elena Beatrice. Jednodětnost v českých rodinách. Kdo jsou ti, kdo mají nebo plánují pouze jedno dítě? Sociologický časopis, 2007, roč. 43, č. 4, s. 699-720. ISSN 0038-0288.

RYCHTAŘÍKOVÁ, Jitka. Diferenční plodnost v České republice podle rodinného stavu a vzdělání v kohortní perspektivě. In HAMPLOVÁ, D., RYCHTAŘíKOVÁ, J., PIKÁLKOVÁ, S. (eds.) Vzdělání, partnerství, reprodukce a rodina. Praha: SoÚ AVČR, 2003, s. 41-83. ISBN 8073300400.

SECCOMBE, Karen. Assessing the Costs and Benefits of Children: Gender Comparisons among Childfree Husbands and Wives. Journal of Marriage and the Family, 1991, roč. 53, č. 1, s. 191-202. ISSN 0022-2445.

SOBOTKA, Tomáš; ŠŤASTNÁ, Anna; ZEMAN, Kryštof; HAMPLOVÁ, Dana; KANTOROVÁ, Vladimíra. Czech Republic: A Rapid Transformation of Fertility and Family Behaviour after the Collapse of State Socialism. Demographic Research, 2008, roč. 19, č. 14, s. 403-454. ISSN 1435-9871.

ŠALAMOUNOVÁ, Petra; ŠAMANOVÁ, Gabriela. Reprodukční záměry mladých lidí. Naše společnost, 2004, roč. 2, č. 1, s. 8-11. ISSN 1214-438x.

ŠAMANOVÁ, Gabriela. Hodnota dítěte v individuálním životě a pro společnost. Naše společnost, 2006, roč. 4, č. 2, s. 10-14. ISSN 1214-438x.

ŠŤASTNÁ, Anna. Druhé dítě v rodině - preference a hodnotové orientace českých žen. Sociologický časopis, 2007, roč. 43, č. 4, s. 721-745. ISSN 0038-0288.

TESTA, Maria Rita. Childbearing Preferences and Family Issues in Europe [online]. 2006. Dostupné na www: $<$ http://ec.europa.eu/public_opinion/archives/ebs/ebs 253 en.pdf $>$

TOMEŠOVÁ BARTÁKOVÁ, Helena. Gender Division of Work and the Labour Market Re-entry of the Czech Women after the Parental Leave. Sociológia, 2010, roč. 42, č. 3, s. 191 -212. ISSN 08736529.

VAN DE KAA, Dirk J. Anchored Narratives: The Story and Findings of Half a Century of Research into the Determinants of Fertility. Population Studies, 1996, roč. 50, č. 3, s. 389-432. ISSN 0032-4728. 
VAN DE KAA, Dirk J. Fertility Preferences: From Changing Value Orientation to New Behavior. In BULATAO, R. A., CASTERLINE, J. B. Population and Development Review (Supplement: Global Fertility Transition), 2001, s. 290-331. ISBN 087834103X.

VAN PEER, Christine; RABUŠIC, Ladislav. Will we Witness an Upturn in European Fertility in the Near Future? In HÖHN, Ch., AVRAMOV, D., KOTOWSKA, I. E. (eds.) People, Population Change and Policies - Lessons from the Population Policy Acceptance Study - Volume 1: Family Change. The Hague: Springer, 2008, s. 215-241. ISBN 978-1-4020-6608-5.

\section{Autorka}

Zdeňka Lechnerová je doktorskou studentkou na Katedře sociologie Fakulty sociálních studií Masarykovy univerzity. Svoji výzkumnou činnost zaměřje především na problematiku reprodukčních strategií mladých lidí a tematiku panelového výzkumu. Je spoluautorkou knihy s názvem Na prahu dospělosti. Partnerství, sex a životní predstavy mladých v současné české společnosti (Dokořán, 2010).

Kontakt: lechnero@fss.muni.cz 